\title{
COMPARATIVE EVALUATION OF DIVERSITY AND HOMOGENEITY OF WEED COMMUNITIES OF WHEAT CROP IN TEHSIL RAZAR DISTRICT SWABI, PAKISTAN
}

\author{
Maqsood Anwar, Shah Khalid and Naveed Akhtar ${ }^{1 *}$
}

\begin{abstract}
The present study explains comparative evaluation of diversity and degree of homogeneity of weed communities of wheat crop. This study was conducted in tehsil Razar district Swabi Khyber Pakhtunkhwa, Pakistan during February-April 2016. A total of 200 quadrats (square shaped) having size $(1 \mathrm{~m} \times 1 \mathrm{~m})$ were placed in 20 randomly selected wheat fields in the study area. Analytical quantitative characters like density, frequency and cover were calculated for each weed species. Twenty weed communities were established in 20 selected sites/stands. Comparative evaluation of diversity revealed that Menhinick's index ranged from 0.61 to 1.72 , Margalef's species richness index ranged from 2.82 to 6.31 , Simpson's diversity index ranged from 0.78 to 0.94 , Shannon-Wiener diversity index varied from 2.13 to 3.24, Pielou's evenness index varied from 0.67 to 0.97 while maturity index ranged from 39.6 to 67.7. Based on Raunkiaer's law of frequency, out of 20 weed communities, 13 communities were found heterogeneous, while, other 7 were homogeneous. Maximum numbers of weed species were distributed in frequency class A, B and E. The heterogeneity of weed communities shows that the area is under heavy biotic pressure. It was concluded that a variety of weed plants infest wheat crop in the study area that may cause a loss to crop yield. For acquiring better yield, it is necessary to take the appropriate chemical, mechanical and biological measurements for weed control.
\end{abstract}

Keywords: Diversity indices, Frequency, Swabi, Weeds, Wheat.

Citation: Anwar, M.; S. Khalid and N. Akhtar. 2021. Comparative Evaluation of Diversity and Homogeneity of Weed Communities of Wheat Crop in Tehsil Razar District Swabi, Pakistan, Pakistan. Pak. J. Weed Sci. Res., 27 (3):297-305.

\footnotetext{
${ }^{1}$ Department of Botany, Islamia College Peshawar-Pakistan.

*Corresponding author's E-mail: n.akhtar@icp.edu.pk
} 


\section{INTRODUCTION}

Razar is a tehsil of district Swabi Khyber Pakhtunkhwa, Pakistan. It lies from $34^{\circ} 6^{\prime} 0^{\prime \prime}$ to $34^{\circ} 23^{\prime} 0^{\prime \prime}$ North latitudes and $72^{\circ} 12^{\prime} 0^{\prime \prime}$ to $72^{\circ} 27^{\prime} 0^{\prime \prime}$ East longitudes. The total area of Razar is approximately $385 \mathrm{~km}^{2}$ and its population is 583,936 as per census of 2017 . The soil of the area is fertile and used for general cropping. It shows great variation in color and texture. Area has harsh climate. Summer is very hot and months of July and August record quite high temperature. A rapid fall in temperature is observed from October onwards. Winter is very cold. January is coldest month. Maximum rainfall is received during the months of July and August (monsoon). Maximum humidity has been recorded in monsoon and in winter in the month of December (Anwar et al., 2015; Anwar et al., 2020).

Weed, general term for any plant growing where it is not wanted. Weeds are unwanted plants growing in cultivated as well as in domesticated areas and adapted to various edaphic and climatic conditions. These are distributed everywhere and no crop is free of weeds. Weeds competes with crops mainly for water, space, light, nutrients and decreases quality as well as quantity of crop (Dangwal et al., 2010). Weeds develop mutualistic relationship with insect pollinators (Jesse et al., 2006) and effectively invade new areas that affect various ecosystems (Morale and Aizen, 2006). Oudhia and Tripathi (1998) reported that some weed plants secrete allelochemicals which affect the growth and germination of agricultural crops. The weed species with high importance value and frequency might compete better to reduce growth and yield of associated crop (Sher et al., 2011). The invasive weeds change the community structure and composition of native plants and as a result create pressure on ecological energetics (Pysek and Richardson, 2007). Species richness (SR) is the number of different species in an ecological community. Species diversity (SD) is the degree of variation in life form within an ecosystem. It refers to variety and variability among the ecosystem and living organisms. Species evenness (SE) is the uniformity of abundance between species in an ecological community. Species maturity (SM) is the proportion of total percentage frequency of all species in a stand. Degree of homogeneity refers to uniform distribution of species in Raunkiaer's frequency classes.

The review reveals that there is no detailed study regarding comparative evaluation of diversity and degree of homogeneity of weed communities of wheat crop in tehsil Razar district Swabi, Pakistan. Therefore, the aim and objectives of the present study were to explore diversity and degree of homogeneity of weed communities of wheat crop in tehsil Razar district Swabi Khyber Pakhtunkhwa, Pakistan. This research will provide baseline knowledge about weed ecology and it will be helpful in future studies.

\section{MATERIALS AND METHODS}

\section{Analytical data}

A total of 20 wheat fields were selected on the basis of floristic composition and physiognomy contrast in study area during 2016. At each field, 10 quadrats (square shaped) having (1m $\times 1 \mathrm{~m})$ size were placed systematically (Hussain, 1989). The number of weed species were counted in each quadrat and analytical quantitative characters i.e. cover, frequency and density were determined for each weed species. The relative value of each quantitative character was added to get the importance value (IV). Twenty weed communities were established on the basis of highest importance value (HIV) of three leading weed species (Hussain, 1989; Ahmad and Shaukat, 2012).

\section{Diversity indices}

Species richness was determined using method of Margalef (1958) and Menhinick (1964). Species diversity was determined after Simpson (1949) and 
Shannon-Wiener (1949). Species evenness was calculated according to Pielou (1975) method. Index of maturity was calculated according to formula of Pichi-Sermolli (1948). Raunkiaer's law of frequency (Raunkiaer, 1934) was used to determined degree of homogeneity.

\section{RESULTS AND DISCUSSION}

\section{Weeds communities}

Twenty weed communities were establis Parthenium (VMP) community, AnagallisCerastium-Veronica (ACV) community, Coronopus-Anagallis-Medicago (CAM) community, Phalaris-Emex-Anagallis (PEA) community, Chenopodium-EmexPhalaris (CEP) community, TrifoliumCynodon-Melilotus (TCM) community, Anagallis-Medicago-Poa (AMP) community, Cynodon-Medicago-Cerastium (CMC) community, Polygonum-AnagallisCynodon (PAC) community, PolygonumCynodon-Medicago (PCM) community, Galium-Anagallis-Phalaris (GAP) community, Poa-Anagallis-Avena (PAA) community, Phalaris-Papaver-Veronica (PPV) community, Anagallis-CoronopusPolygonum (ACP) community, StellariaPoa-Anagallis (SPA) community and Cynodon-Veronica-Medicago (CVM) community. These communities were floristically diverse due to diverse edaphic variables and favorable growth seasons. Spring is a favorable growth season for the growth of most weed plants. There is always a bloom of annual plants in the spring and early summer. Badshah et al. (2013) stated that generally spring and summer have higher number of species than other seasons. While studying weeds of wheat, other workers (Qureshi and Bhatti, 2001; Jakhar et al., 2005; Qureshi et al., 2009; Waheed et al., 2009; Sher et al., 2011; Malik et al., 2013) recognized weed communities in wheat crop fields in different parts of Pakistan. These studies support the present findings.

\section{Diversity indices}

Species richness, species diversity and species evenness were determined for each weed community. Comparative evaluation of diversity revealed that Menhinick's index ranged from 0.61 to 1.72, Margalef's richness ranged from 2.82 to 6.31 , Simpson's diversity index ranged from 0.78 to 0.94 , ShannonWiener diversity index varied from 2.13 to 3.24 while Pielou's evenness index varied from 0.67 to 0.97 (Table-1, Figure 1). Sher et al. (2011) determined diversity indices for four weed communjijes of wheat in village Lahor district Swabl, pakistan. In comparison to them, the current research found maximum species richness and diversity. These are attributable to extensive exploration from diverse habitats and are due to diverse edaphic variables. Similar work was also conducted in Himalayan forests vegetation of Pakistan (Shaheen et al., 2011; Amjad et al., 2014).

\section{Species maturity and degree of homogeneity}

Highest maturity index (67.7) was observed for Fumaria-Medicago-Anagallis community and lowest (39.6) for Polygonum-Cynodon-Medicago community (Table-1, Figure 2). A mature community is indicated by value more than $60 \%$. Based on Raunkiaer's law of frequency, out of 20 weed communities, 13 communities were found heterogeneous while 7 were homogeneous. Maximum number of weed species were distributed in frequency class A, B and $E$ (Table-2). Majority of weed communities showed heterogeneity due to the presence of large number of annual weeds. The heterogeneity of weed communities shows that the area is under heavy biotic pressure. Sher et al. (2011) found maturity index for four weed communities of wheat in village Lahor, district Swabi, Pakistan. In comparison to them, the current research found highest maturity index. This is due to diverse habitats and diverse edaphic variables. Raunkiaer's law of frequency is called normal frequency ratio which helps in testing the uniformity of vegetation (Khan et al., 2012). Various climatic, biotic and edaphic factors, species composition, distribution, particular growth-form and life form affect 
homogeneity of plant communities in different seasons in particular area.

\section{CONCLUSIONS}

The present findings suggest that a large number of weed plants infest wheat crop in the study area that cause loss to crop yields on large scale. For acquiring better yield, it is important to take appropriate biological, chemical and mechanical measure for weed control. This information about weed biology can be helpful for the selection of weed control methods and will provide baseline knowledge about weed ecology and will be helpful in future studies. 
Table-1. Comparative evaluation of diversity indices of weed communities of wheat crop in tehsil Razar district Swabi, Pakistan.

\begin{tabular}{|c|c|c|c|c|c|c|c|c|}
\hline \multirow{2}{*}{$\begin{array}{l}\text { S. } \\
\text { No. }\end{array}$} & \multirow[b]{2}{*}{ Weed Communities } & \multirow{2}{*}{$\begin{array}{c}\text { Total } \\
\text { species }\end{array}$} & \multicolumn{2}{|c|}{ Species Richness } & \multicolumn{2}{|c|}{ Species Diversity } & \multirow{2}{*}{$\begin{array}{c}\text { Evenness } \\
\text { Pielou }\end{array}$} & \multirow{2}{*}{$\begin{array}{l}\text { Maturity Index } \\
\text { Pichi-Sermoli }\end{array}$} \\
\hline & & & Menhinick & Margalef & Simpson & $\begin{array}{c}\text { Shannon- } \\
\text { Wiener }\end{array}$ & & \\
\hline $\mathbf{1}$ & Polypogon-Rananculus-Veronica community & 25 & 1.17 & 3.92 & 0.81 & 2.17 & 0.67 & 42.0 \\
\hline 2 & Melilotus-Medicago-Rananculus community & 21 & 1.40 & 3.69 & 0.89 & 2.45 & 0.81 & 44.7 \\
\hline 3 & Fumaria-Medicago-Anagallis community & 27 & 1.22 & 4.20 & 0.94 & 3.05 & 0.92 & 67.7 \\
\hline 4 & Fumaria-Medicago-Phalaris community & 21 & 1.01 & 3.29 & 0.87 & 2.35 & 0.77 & 50.9 \\
\hline 5 & Veronica-Medicago-Parthenium community & 15 & 1.33 & 2.89 & 0.90 & 2.44 & 0.91 & 43.3 \\
\hline 6 & Anagallis-Cerastium-Veronica community & 15 & 1.33 & 2.89 & 0.89 & 2.32 & 0.86 & 44.0 \\
\hline 7 & Coronopus Anagallis-Medicago community & 26 & 1.14 & 4.00 & 0.89 & 2.59 & 0.79 & 45.0 \\
\hline 8 & Phalaris-Emex-Anagallis community & 21 & 1.10 & 3.39 & 0.78 & 2.13 & 0.71 & 43.8 \\
\hline 9 & Chenopodium-Emex-Phalaris community & 22 & 1.43 & 3.85 & 0.91 & 2.67 & 0.86 & 46.8 \\
\hline 10 & Trifolium-Cynodon-Melilotus community & 20 & 1.44 & 3.61 & 0.86 & 2.25 & 0.75 & 41.0 \\
\hline 11 & Anagallis-Medicago-Poa community & 21 & 0.61 & 2.82 & 0.83 & 2.15 & 0.71 & 57.1 \\
\hline 12 & Cynodon-Medicago-Cerastium community & 25 & 0.87 & 3.57 & 0.90 & 2.62 & 0.81 & 60.8 \\
\hline 13 & Polygonum-Anagallis-Cynodon community & 41 & 1.72 & 6.31 & 0.94 & 3.24 & 0.87 & 52.4 \\
\hline 14 & Polygonum-Cynodon-Medicago community & 32 & 1.63 & 5.21 & 0.91 & 2.71 & 0.78 & 39.6 \\
\hline 15 & Galium-Anagallis-Phalaris community & 23 & 0.94 & 3.44 & 0.92 & 2.76 & 0.88 & 65.6 \\
\hline 16 & Poa-Anagallis-Avena community & 26 & 1.13 & 3.98 & 0.91 & 2.71 & 0.83 & 51.5 \\
\hline 17 & Phalaris-Papaver-Veronica community & 22 & 0.91 & 3.31 & 0.90 & 2.53 & 0.82 & 55.4 \\
\hline 18 & Anagallis-Coronopus-Polygonum community & 34 & 1.33 & 5.09 & 0.93 & 3.04 & 0.86 & 58.5 \\
\hline 19 & Stellaria-Poa-Anagallis community & 32 & 1.48 & 5.04 & 0.92 & 2.85 & 0.97 & 41.8 \\
\hline 20 & Cynodon-Veronica-Medicago community & 21 & 0.91 & 3.19 & 0.84 & 2.31 & 0.76 & 48.7 \\
\hline
\end{tabular}


Table-2. Degree of homogeneity of weed communities of wheat crop in tehsil Razar district Swabi, Pakistan.

\begin{tabular}{|c|c|c|c|c|c|c|c|c|c|}
\hline \multirow{2}{*}{ S. No. } & \multirow{2}{*}{ Weed Communities } & \multirow{2}{*}{$\begin{array}{l}\text { Total } \\
\text { species }\end{array}$} & \multicolumn{5}{|c|}{$\begin{array}{l}\text { Distribution of species } \\
\text { in frequency classes }\end{array}$} & \multirow{2}{*}{$\begin{array}{c}\text { Raunkiaer's } \\
\text { Homogeneity Equation }\end{array}$} & \multirow[t]{2}{*}{ Remarks } \\
\hline & & & $\mathbf{A}$ & B & $\mathbf{C}$ & $\mathbf{D}$ & $\mathbf{E}$ & & \\
\hline 1 & Polypogon-Rananculus-Veronica community & 25 & 13 & 4 & 2 & 0 & 6 & $A>B>C>D<E$ & Homogeneous \\
\hline 2 & Melilotus-Medicago-Rananculus community & 21 & 11 & 2 & 1 & 3 & 4 & $A>B>C<D<E$ & Heterogeneous \\
\hline 3 & Fumaria-Medicago-Anagallis community & 27 & 2 & 2 & 5 & 12 & 6 & $A=B<C<D>E$ & Heterogeneous \\
\hline 4 & Fumaria-Medicago-Phalaris community & 21 & 6 & 5 & 3 & 2 & 5 & $A>B>C>D<E$ & Homogeneous \\
\hline 5 & Veronica-Medicago-Parthenium community & 15 & 5 & 3 & 3 & 3 & 1 & $A>B=C=D>E$ & Heterogeneous \\
\hline 6 & Anagallis-Cerastium-Veronica community & 15 & 6 & 3 & 2 & 1 & 3 & $A>B>C>D<E$ & Homogeneous \\
\hline 7 & Coronopus Anagallis-Medicago community & 26 & 6 & 9 & 5 & 2 & 4 & $A<B>C>D<E$ & Heterogeneous \\
\hline 8 & Phalaris-Emex-Anagallis community & 21 & 7 & 7 & 1 & 3 & 3 & $A=B>C<D=E$ & Heterogeneous \\
\hline 9 & Chenopodium-Emex-Phalaris community & 22 & 5 & 8 & 4 & 2 & 3 & $A<B>C>D<E$ & Heterogeneous \\
\hline 10 & Trifolium-Cynodon-Melilotus community & 20 & 11 & 3 & 1 & 0 & 5 & $A>B>C>D<E$ & Homogeneous \\
\hline 11 & Anagallis-Medicago-Poa community & 21 & 6 & 0 & 7 & 4 & 4 & $A>B<C>D=E$ & Heterogeneous \\
\hline 12 & Cynodon-Medicago-Cerastium community & 25 & 4 & 4 & 7 & 3 & 7 & $A=B<C>D<E$ & Heterogeneous \\
\hline 13 & Polygonum-Anagallis-Cynodon community & 41 & 7 & 9 & 12 & 8 & 5 & $A<B<C>D>E$ & Heterogeneous \\
\hline 14 & Polygonum-Cynodon-Medicago community & 32 & 15 & 5 & 4 & 3 & 5 & $A>B>C>D<E$ & Homogeneous \\
\hline 15 & Galium-Anagallis-Phalaris community & 23 & 2 & 5 & 4 & 3 & 9 & $A<B>C>D<E$ & Heterogeneous \\
\hline 16 & Poa-Anagallis-Avena community & 26 & 8 & 5 & 4 & 3 & 6 & $A>B>C>D<E$ & Homogeneous \\
\hline 17 & Phalaris-Papaver-Veronica community & 22 & 7 & 3 & 1 & 4 & 7 & $A>B>C<D<E$ & Heterogeneous \\
\hline 18 & Anagallis-Coronopus-Polygonum community & 34 & 4 & 10 & 5 & 7 & 8 & $\mathrm{~A}<\mathrm{B}>\mathrm{C}<\mathrm{D}<\mathrm{E}$ & Heterogeneous \\
\hline 19 & Stellaria-Poa-Anagallis community & 32 & 12 & 7 & 6 & 3 & 4 & $A>B>C>D<E$ & Homogeneous \\
\hline 20 & Cynodon-Veronica-Medicago community & 21 & 7 & 3 & 6 & 1 & 4 & $A>B<C>D<E$ & Heterogeneous \\
\hline
\end{tabular}




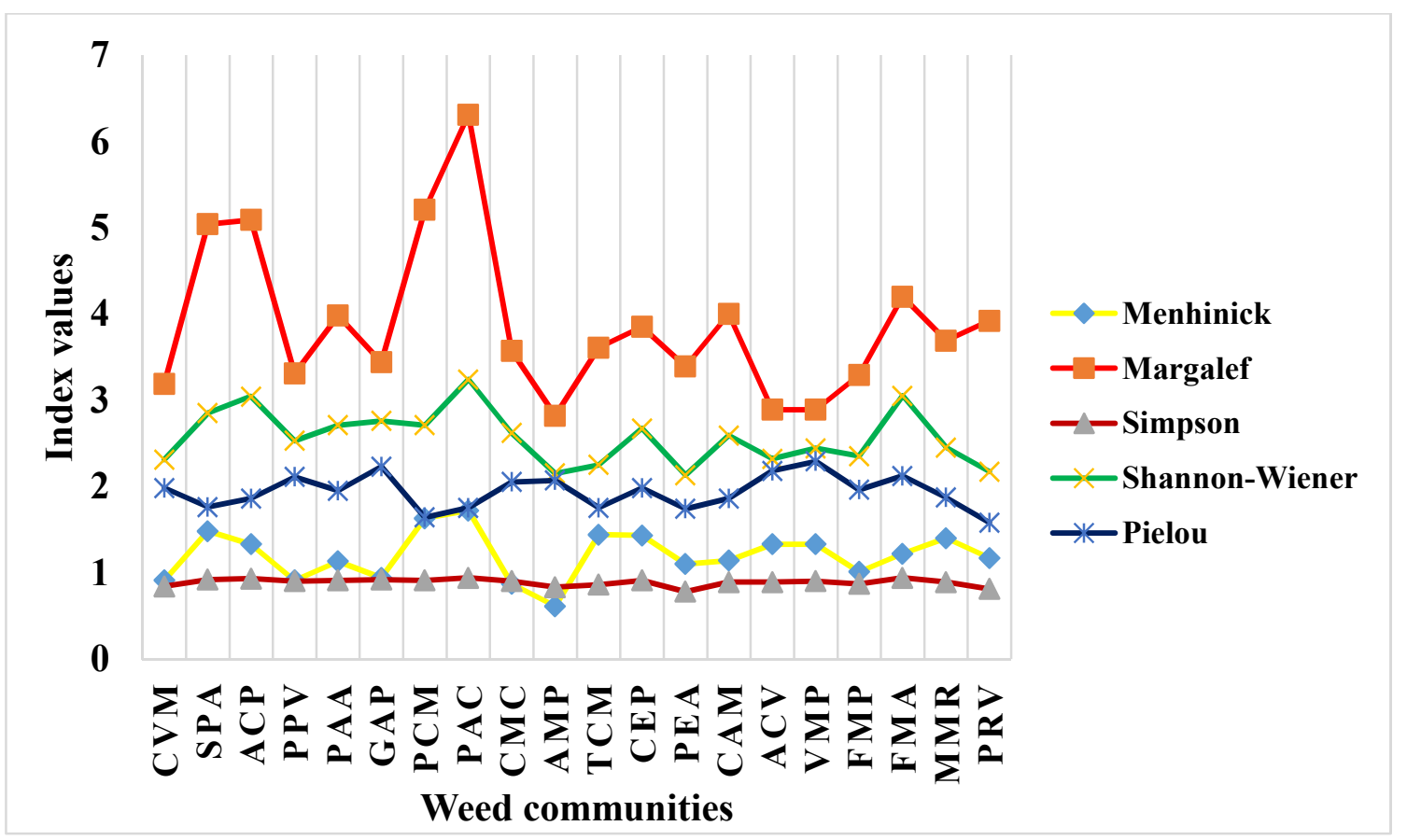

Figure 1. Comparative evaluation of diversity of weed communities of wheat crop in tehsil Razar district Swabi.

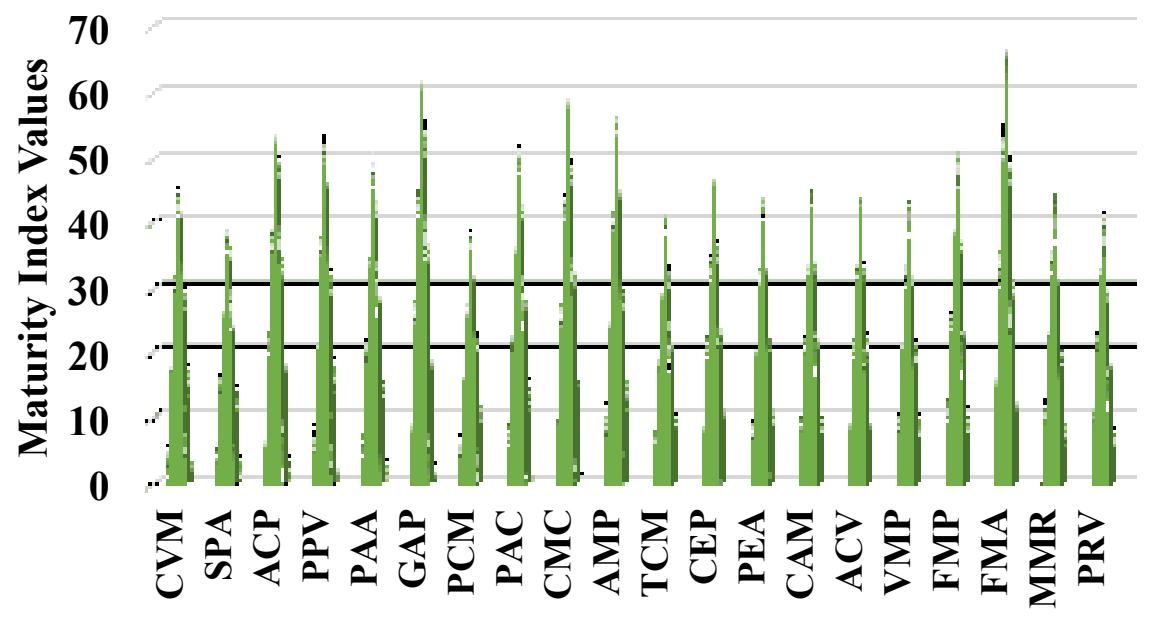

Weed Communities

Figure 2. Maturity index of weed communities of wheat crop in tehsil Razar district Swabi. 


\section{REFERENCES CITED}

Ahmad, M. and S.S. Shaukat. 2012. A text book of Vegetation Ecology. $1^{\text {st }}$ Ed. Abrar Sons; Karachi (Pakistan), pp. 29-76.

Amjad, M.S., M. Arshad and S.K. Chaudhari. 2014. Structural diversity, its components and regenerating capacity of lesser Himalayan forests of Nikyal valley District Kotli (A.K), Pakistan. Asian. Pac. J. Trop. Med., 7(S1): 454-460.

Anwar, M., N. Akhtar, S. Khalid and H. Zeb. 2020. Eco-Floristic Study of Weed Flora of Maize Crop in District Swabi, Khyber Pakhtunkhwa, Pakistan. Pak. J. Weed Sci. Res., 26(4): 499-506.

Anwar, M., W.M. Khan, M.S. Khan, W. Murad and S. Ali. 2015. Taxonomic study of Family Papilionaceae of District Swabi, Khyber Pakhtunkhwa, Pakistan. Pure Appl. Biol., 4(1):125128.

Badshah, L., F. Hussain and Z. Sher. 2013. Floristic inventory, ecological characteristics and biological spectrum of rangeland, district Tank, Pakistan. Pak. J. Bot., 45(4): 11591168.

Dangwal, L.R, A. Singh, T. Singh, A. Sharma and C. Sharma. 2010. "Common weeds of Rabi (winter) crops of Tehsil Nowshera, District Rajouri (Jammu \& Kashmir), India." Pak. J. Weed Sci. Res., 16(1):39-45.

Hussain, F. 1989. Field and Laboratory Manual for Plant Ecology. University Grants Commission; Islamabad.

Jakhar, G.S., A.Q. Mahar, S.A. Abro and R. Qureshi. 2005. Weed communities of wheat crop under diverse Edaphography of District Khairpur. Pak. J. Bot., 37(3):709-714.

Jesse, L.C., K.A. Moloney and J.J. Obrycki. 2006. Insect visitors of invasive plant Rosa multiflora (Rosaceae), In Lowa, USA. Weed Biol. Manage., 6: 235340.
Khan, M., F. Hussain and S. Musharaf. 2012. Degree of homogeneity of plant life in tehsil Takht-e-Nasrati, Pakistan. Global. J. Sci. Front. Res., 12(4):1.

Malik, Z.H., M.S. Amjad, S. Rafique and N.Z. Malik. 2013. Phytosociology of some weeds of wheat communities around Kotli fields, Western Himalaya. J. Eco. Nat. Envi., 5(11): 340-345.

Margalef, R. 1958. Temporal Succession and Spatial Heterogeneity in Natural Phytoplankton. In Perspectives in Marine Biology; Buzzati-Traverso, A.A., Ed.; University of California Press: Berkeley, CA, USA, pp. 323349.

Menhinick, E.F. 1964. A comparison of some species-individuals diversity indices applied to samples of field insects. Ecology, 45 (4): 859-861.

Morale, C.L. and M.A. Aizen. 2006. Invasive mutualism and the structure of plant-pollinators interaction in temperate forest of northwest Patagonia, Argentina. J. Ecol., 94: 171-180.

Oudhia, P. and R.S. Tripathi. 1998. Allelopathic effects of Parthenium hysterophorus L. on kodo mustard and problematic weeds. 1st Int. Conf. Parthenium management UAS, Dhaward, India, 6-8 Oct. 1997: 136139.

Pichi-Sermolli, R.E. 1948. An index for establishing the degree of maturity in plant communities. J. Eco., 36: 85-90.

Pielou, E.C. (1975). Ecological diversity: Wiley New York.

Pysek, P. and D.M. Richardson. 2007. Traits associated with invasiveness in alien plants: where do we stand? In: Nentwig W (ed) Biological invasions. Springer, Berlin, pp. 97-126.

Qureshi, R., A. Waheed and M. Arshad. 2009. Weed communities of wheat crop in district Toba Tek Singh, Pakistan. Pak. J. Bot., 41(1): 239245. 
Qureshi, R. and G.R. Bhatti. 2001. Determination of weed communities of wheat (Triticum aestivum L.) fields of district Sukkur. Pak. J. Bot., 33(1): 109-115.

Raunkiaer, C. 1934. The life form of plants and statistical plant geography. The Clarendon Press, Oxford.

Shaheen, H., S.M. Khan, D.M. Harper, Z. Ullah and R.A. Qureshi. 2011. Species diversity, community structure and distribution patterns in Western Himalayan Alpine Pastures of Kashmir, Pakistan. Mountain. Res. Dev., 31(2):153-159.

Shannon, C.E. and W. Wiener. 1949. The mathematical theory of communication. Urbana, University of Illinois Press, $177 \mathrm{p}$.

Sher, Z., F. Hussain, L. Badshah and M. Wahab. 2011. Floristic composition, communities and ecological characteristics of weeds of wheat fields of Lahor, District Swabi, Pakistan. Pak. J. Bot., 43(6): 28172820.

Simpson, E.H. 1949. Measurement of diversity. Nature, 163: 688.

Waheed, A., R. Qureshi, G.S. Jakhar and H. Tareen. 2009. Weed community dynamics in wheat crop of district Rahim Yar Khan, Pakistan. Pak. J. Bot., 41: 247-254. 